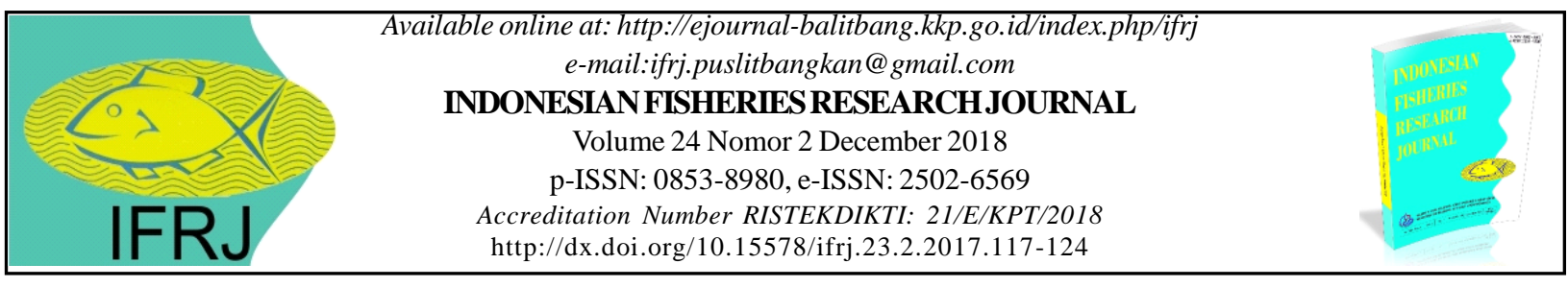

\title{
POPULATION CHARACTERISTICS OF MUD CRAB (Scylla serrata) IN THE WATERS OF KENDARI BAY AND SURROUNDING AREAS
}

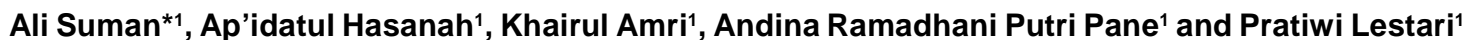 \\ ${ }^{1}$ Marine Fisheries Research Institute, Jl. Raya Bogor KM. 47 Nanggewer Mekar, Cibinong, Bogor, West Java, Indonesia \\ Received; February 07-2018 Received in revised from August 28-2018; Accepted September 17-2018
}

\begin{abstract}
The high market demand for mud crabs (Scylla serrata) has caused intensive fishing for this resources and tended to threaten their sustainability. Studies of population characteristics are the main bases for formulating management measures for sustainable utilization. The purpose of this study was to determine the population characteristics of mud crabs in the waters of Kendari Bay and its surrounding waters. The study was conducted from January to November 2016 using survey method. The study results revealed that the mud crab growth pattern in Kendari Bay was negative allometric and that the ratio of males and females was imbalance. The length at first maturity $(L m)$ was at a carapace width of $109.8 \mathrm{~mm}$. The growth rate $(K)$ was 1.01 per year and the maximum carapace width $\left(L_{\infty}\right)$ was $206 \mathrm{~mm}$. The estimated total mortality rate $(Z)$, fishing mortality rate $(F)$, and natural mortality rate $(M)$ were 3.20 per year, 2.17 per year, and 1.03 per year, respectively. The exploitation rate $(E)$ was 0.68 per year. Therefore, the exploitation rate had reached $136 \%$, which is categorized as overfishing. In order to ensure the sustainability of the mud crabs, there is needed to apply the precautionary approach, such as reducing fishing effort by $36 \%$ of the current situation.
\end{abstract}

\section{Keywords: Mud crab; population characteristics; Kendari Bay and its adjacent waters; Fisheries Management Area (FMA) 714}

\section{INTRODUCTION}

Mud crab (Scylla spp.) is one of the important fishery commodities with a high economic value in Southeast Asia (Le Vay, 1998; Cristensen et al., 2004). This commodity also has a lot of potentials to be developed in aquaculture (Kathirvel et al., 2004; Ruscoe et al., 2004; Mohanty et al., 2006) with an average annual production at around 24,000 tons in the Indo-Pacific Zone. The growing popularity of mud crabs is due to their large size and palatable and nutritious meat (Marichamy \& Rajapackian, 2001).

In Indonesia, mud crab has became an important fishery commodity with a high economic value since 1980 (Cholik, 1999) and still produced until recent years with production about 43, 444 ton in 2016 (DGCF, 2017). There are four common species of mud crabs in Indonesia: Scylla serrata, S. tranquebarica, S. olivacea, and S. paramamosain thatdominated by S. serrata, which accounts for approximately $80 \%$ of totalmud crabs (Keenan et al., 1998).
Mud crab (Scylla serrata) is one of the important economic commodities for coastal fisheries in Kendari Bay waters and surrounding areas. The utilization has been already very intensive using crab traps (locally known as rakang). In recent years, the domestic and export market demand for mud crabs is increasing from 90,763 tons in 2012 to 109,624 tons in 2015 (CBS, 2018) and there were concerns that this would cause crab fishing pressure to become more intensive. The high exploitation rate could threaten their sustainability and in long term might cause depletion of mud crab resources. In order to ensure the management of mud crab resources in Kendari Bay waters, there is a need to apply sustainable management. The basis of management requires information from research-based observation, especially population characteristics.

To this moment, there is a lack of information on the population characteristics of mud crabs in Kendari Bay waters. Therefore, this article will discuss the population characteristics of mud crabs in Kendari 
Bay waters and surrounding areas. The results of this study are expected to be used for management purposes and as a basis for further research about mud crabs.

\section{MATERIALS AND METHODS}

This study was conducted in Kendari Bay waters and surrounding areas (Figure 1) during a period of
January 2016 to November 2016. Data were collected through monthly based survey method assisted by well-trained enumerators. Observations and measurements of the mud crab samples were done at mud crab wholesale and fisher center levels in Kendari Bay waters and the surrounding areas. The geographical location of the mud crab fishing area is at $3^{\circ} 57^{\prime}$ 'South Latitude-112 $2^{\circ} 37^{\prime}$ East Longitude and $3^{\circ} 5$ South Latitude $-112^{\circ} 36^{\prime}$ East Longitude.

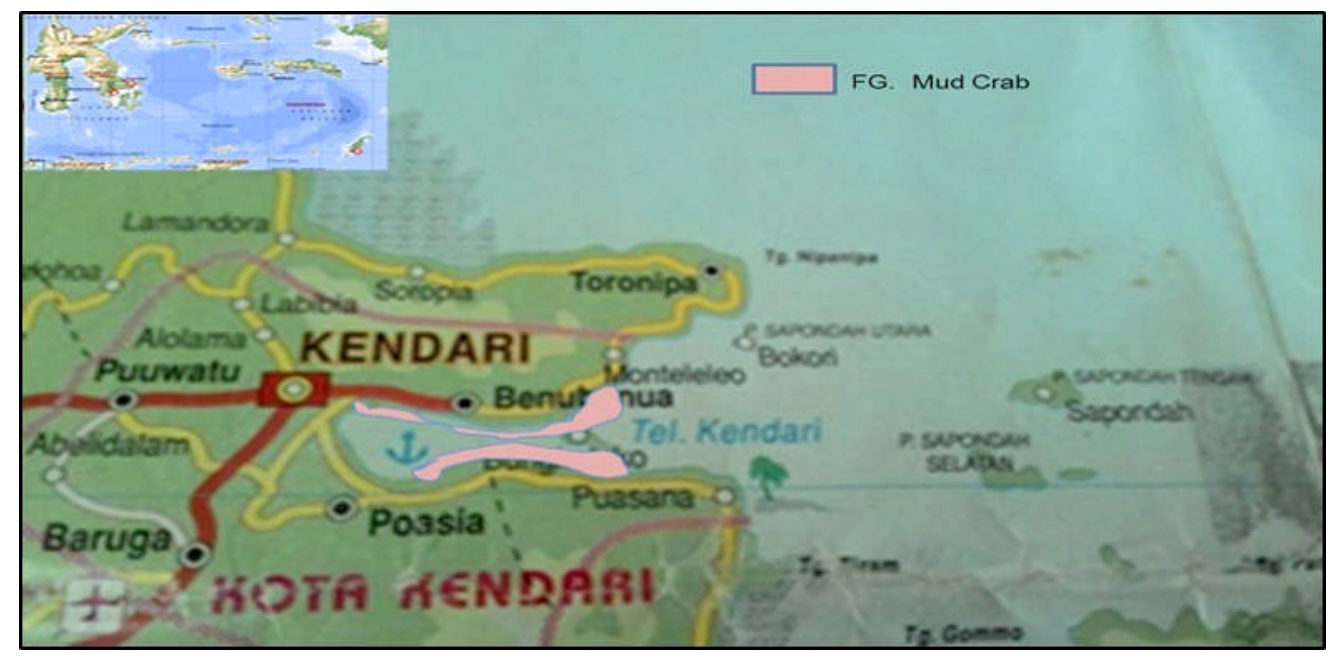

Figure 1. Fishing ground of mud crabs (Scylla serrata) in Kendari Bay waters (Source : Kembaren et al., 2015).

The biological aspects of mud crab that were observed included carapace width, weight, and gonad maturity level. The relationship between carapace width and body weight followed the equation (Ball \& Rao, 1984):

$W=a L^{b}$

where:

$W=$ body weight $(\mathrm{g})$,

$L=$ carapace width $(\mathrm{mm})$,

$a=$ a constant (a scaling coefficient for the weight at a length)

$b=$ is a value representing shape parameter for the body form of the species

The growth parameter ( $K$ and $\left.L_{\infty}\right)$ were determined through the length-based approach and using the ELEFAN method (Gayanilo et al., 1993). The total mortality rate $(Z)$ was estimated by using linearized catch curve method, which was the slope $(b)$ between Ln N/t and the relative age (Sparre \& Venema, 1999), according to the following equation:

$\operatorname{Ln} N / t=a-Z t$

where:

$N=$ number of crabs at time $t$ $t=$ time needed to grow one length class

$a=$ the catch results converted to length

The estimation of the crab's natural mortality rate was conducted using the empirical formula by Pauly (1980) as follows:

$\log M=-0,0066-0,279 \log L_{\infty}+0,654 \log K+$

$$
0,4534 \text { og } T
$$

where:

$M=$ natural mortality

$L=$ maximum carapace width $(\mathrm{mm})$

$K=$ growth rate $(\mathrm{mm} /$ year $)$

$T=$ temperature $\left({ }^{\circ} \mathrm{C}\right)$

The fishing mortality rate was obtained from the total mortality rate $(Z)$ and natural mortality rate $(M)$ by the following equation (Sparre \& Venema, 1999):

$F=Z-M$

The exploitation rate $(E)$ was calculated as

$E=F / Z$ 


\section{RESULTS AND DISCUSSION}

Results

\section{The Relationship Between Carapace Width and Body Weight and Sex Ratio}

The carapace width of mud crabs ranged from 85 $\mathrm{mm}$ to $205 \mathrm{~mm}$ and the dominant size was in a class interval of 105-140 mm (Figure 2). In Figure 2, it can be seen that male crab had larger carapace width than the female's one.

The relationship between carapace width and body weight had a value of $b=2.1284$. This value signified a negative allometric relationship, which means that the body width increase was faster than the body weight gain.

The ratio between male and female mud crabs ( $S$. serrata) in the waters of Kendari Bay and surrounding areas was $1.0: 0.51$ and the chi-square test revealed that the sex ratio was imbalanced.

\section{The Length at First Capture (LC) and he Length at First Maturity (Lm)}

Based on the analysis results, the $L c$ value for mud crabs in the waters of Kendari Bay was 115.3 $\mathrm{mm}$ (Figure 3).

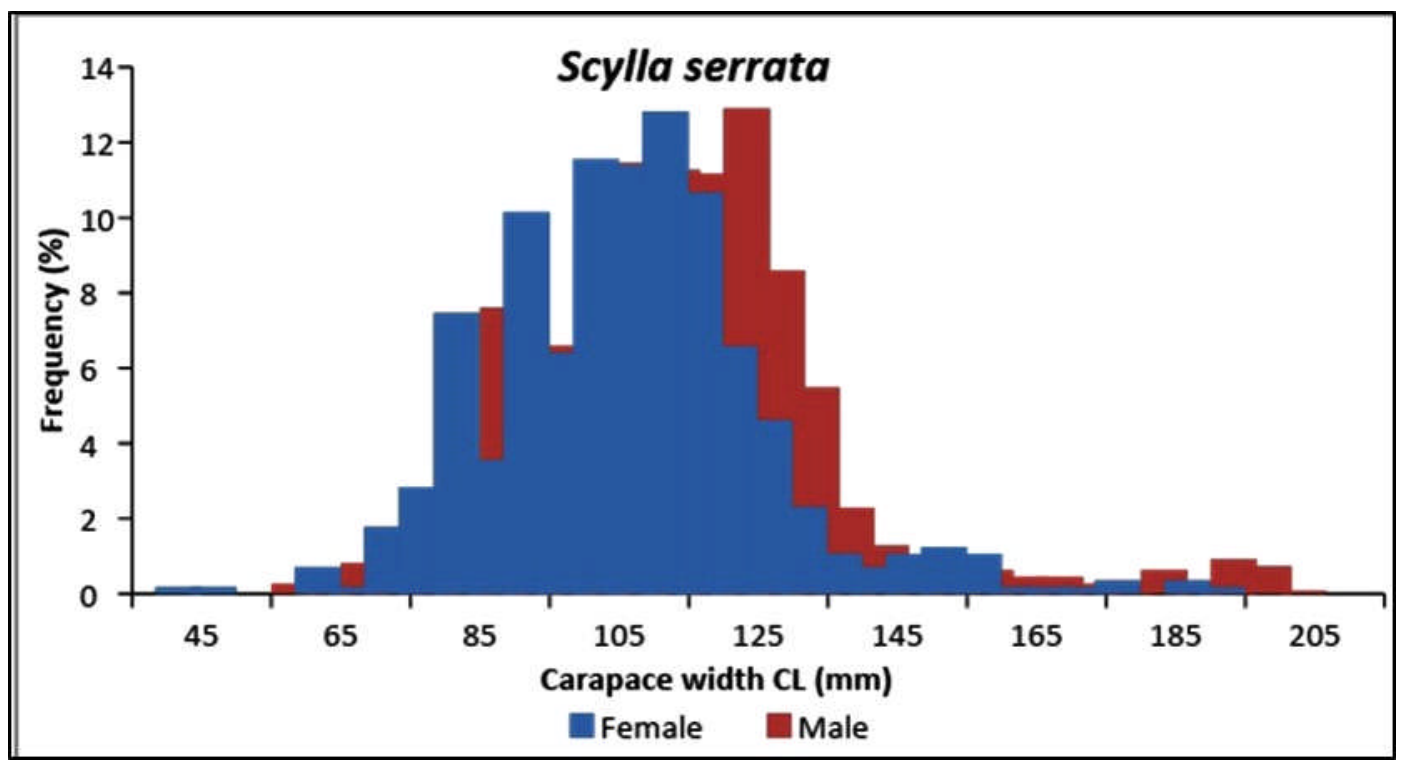

Figure 2. The carapace width frequency of mud crabs (Scylla serrata) in Kendari Bay and its adjacent waters.

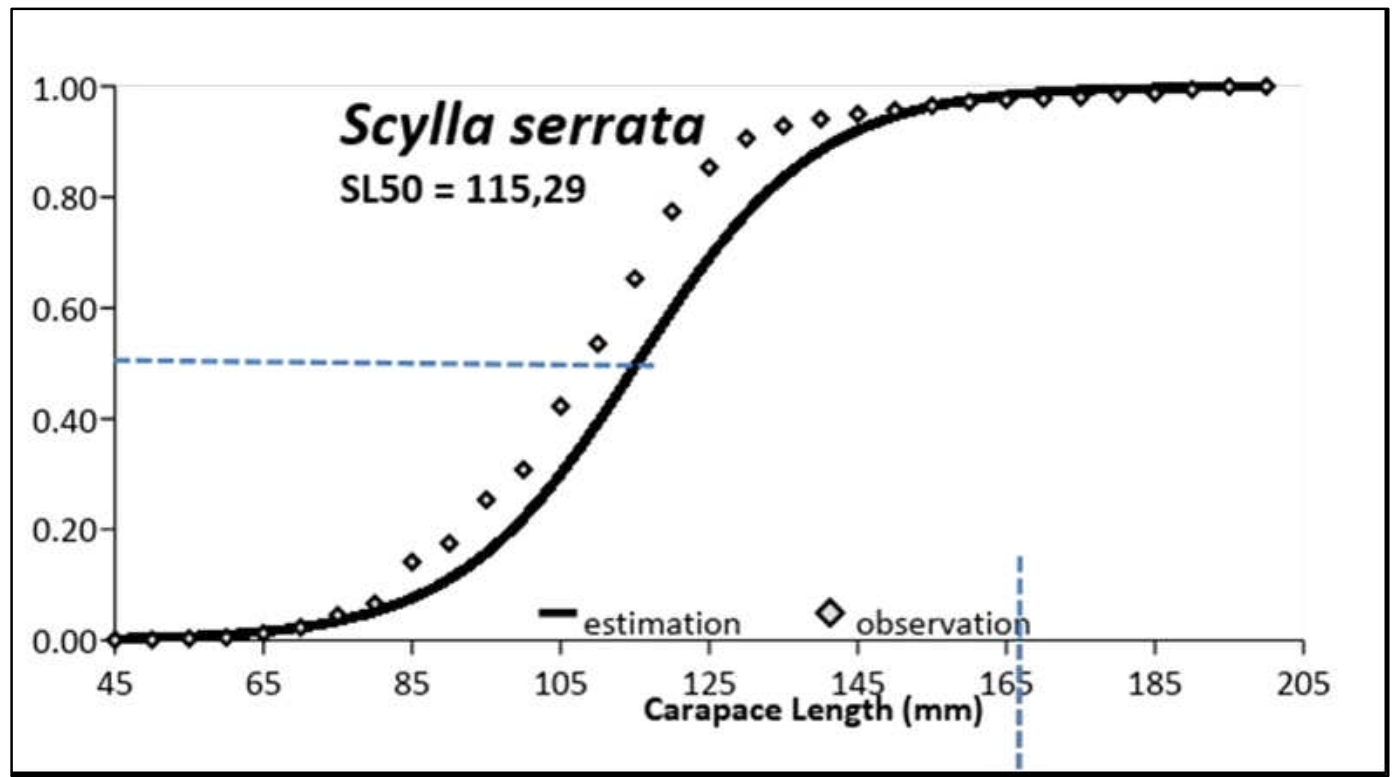

Figure 3. Length at first capture of mud crabs (S. serrata) in Kendari Bay and surrounding waters. 
The further analysis found that the $L m$ value was $109.8 \mathrm{~mm}$ (Figure 4). Based on these results, it can be seen that the $L_{c}$ value was greater than the $L_{m}$ value and this signified that the crabs caught have spawned.

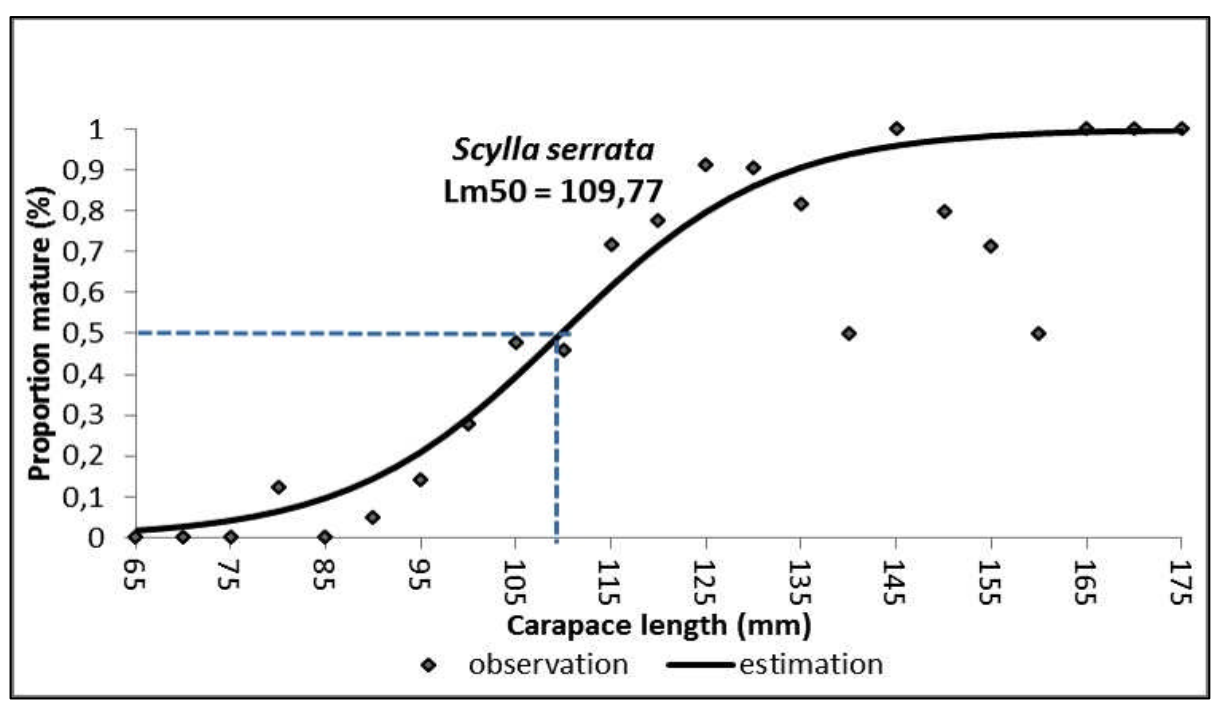

Figure 4. Length at first maturity $\left(L_{m}\right)$ of mud crab (S. serrata) in Kendari Bay waters.

\section{Growth Parameters}

By studying the modal progression of monthly based measurements of carapace width frequency data, the growth rate $(K)$ of mud crabs in the waters of Kendari Bay and surrounding areas was 1.01 per year and the estimation maximum carapace width $\left(L_{\infty}\right)$ was $206.0 \mathrm{~mm}$ (Figure 5).

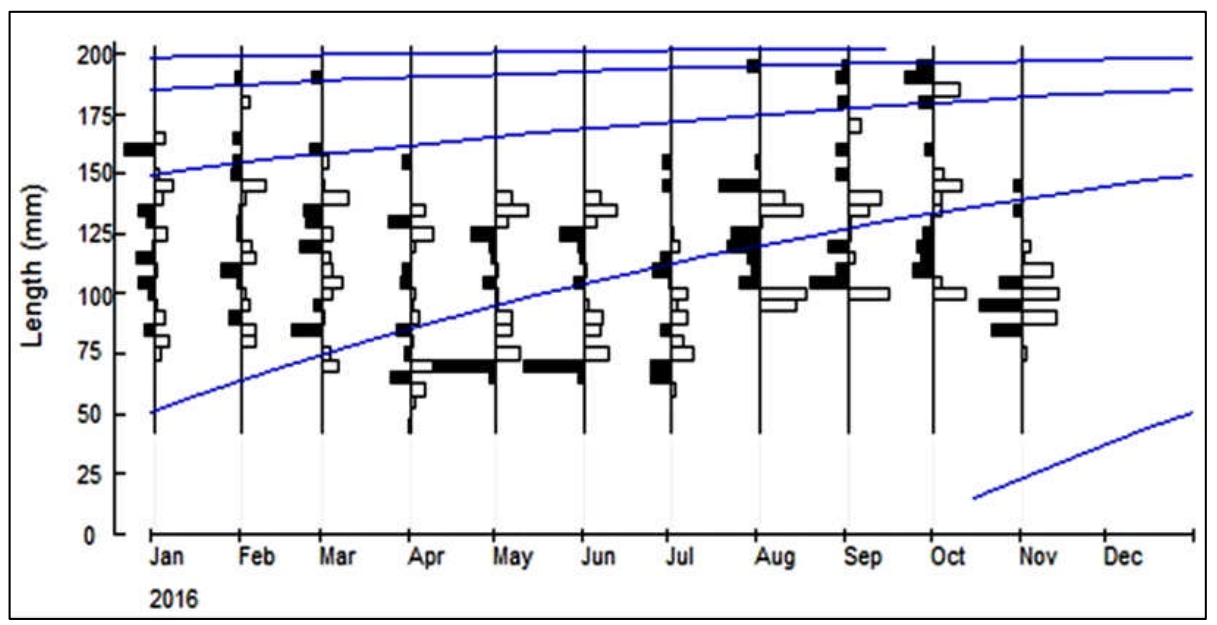

Figure 5. Von Bertalanffy growth curve of mud crabs (S. serrata) in Kendari Bay waters.

\section{Estimates of Mortality and Exploitation Rates}

Using the calculated mud crabs growth parameter ( $K=1.01$ per year, $L_{\infty}=206.0 \mathrm{~mm}$ ) as input for developing a capture curve, the estimated $Z$ value was
3.20 per year (Figure 6). The estimated natural mortality rate $(M)$ was calculated using the equation by Pauly (1980) and resulted in the Mvalue was 1.03 per year. The estimate of fishing mortality rate $(F)$ was calculated and the result was 2.17 per year. 


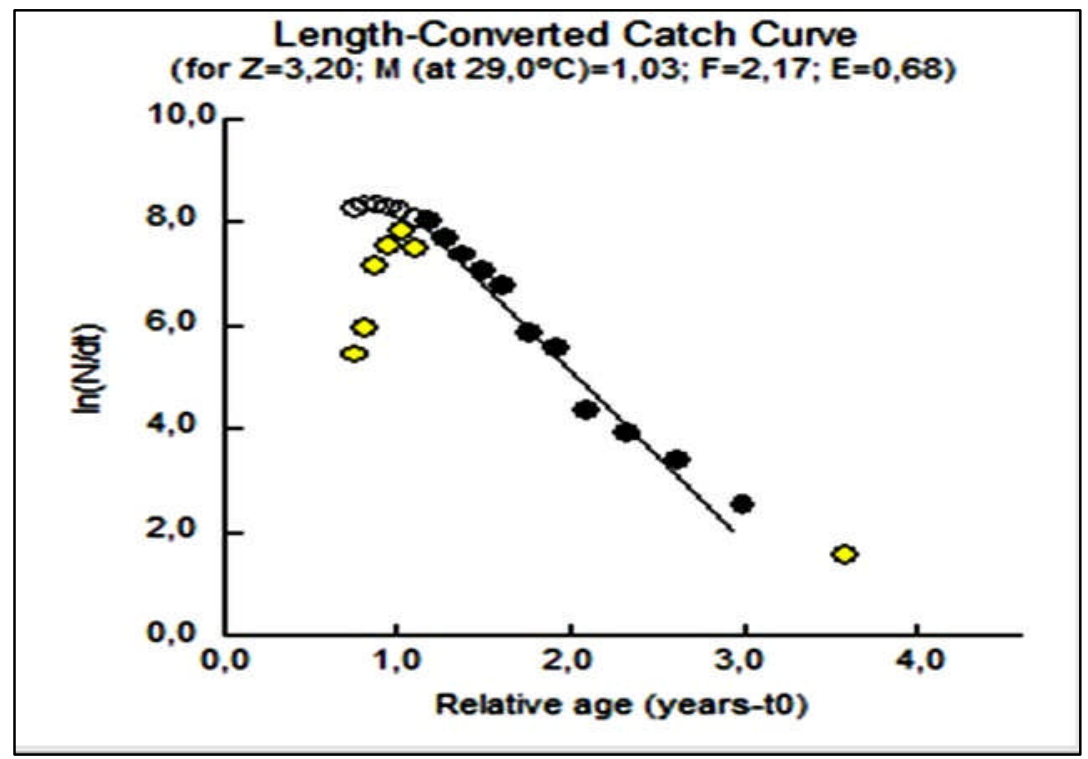

Figure 6. Length-converted catch curve of mud crabs (S. serrata) in Kendari Bay waters.

Using the value of $F$, which is the reflection of fishing pressure, and the value of $Z$, which is the reflection of the total mortality rate due to fishing and natural reasons, the exploitation rate $(E)$ of mud crabs was 0.68 per year. The value of $E$ suggested that the exploitation rate ofmud crabs in Kendari Bay waters and surrounding areas was already within the overfishing category.

\section{Discussion}

The analysis of the relationship between carapace width and weight was used to predict the growth pattern of mud crabs in the waters of Kendari Bay and surrounding areas. The result of t-test showed that the growth pattern was negative allometric $(p>005)$. This growth pattern suggested that the increase in body width was faster than the weight gain. This differed from the results obtained by Alamsyah \& Megawati (2017), who found that the growth pattern of mud crabs in the waters of East Sinjai was isometric. An isometric growth pattern signifies that the weight and carapace width increase was balanced. This difference occurred because the individual growth pattern depends on the availability of food and the water temperature (Monterio, 2002 in Fauzi et al., 2013). The differences in length increase could also be caused by the differences in external and internal factors. According to Effendie (2002), internal factors are factors that are difficult to control, such as genetics, sex, age, and diseases. On the other hand, the main external factors that influence fish growth are temperature and food.
The ratio between male and female mud crabs in the waters of Kendari Bay was imbalanced, where the male mud crabs were more dominant. The imbalanced ratio would demand extra care in the capture. This is related to the possibility of an inhibited repopulation due to the decrease in the female mud crab population. This phenomenon was also observed in the waters of Mayangan, Subang (Syam et al, 2011). This was different from the case in the estuary of Cenranae River, South Sulawesi, where the ratio between male and females was balanced (Gunarto et al, 1999). The cause of the differences in male-female ratios could be due to fishing pressure and migration factors (Suman, 2004; Edrus \& Syam, 2004).

The length at first maturity $\left(L_{m}\right)$ of mud crabs is important in fishery management because exploitation must leave a number of female broodstock (crabs) that are that particular size or larger when they reach maturity (Sudjastani, 1974). The length at first maturity in the waters of Kendari Bay was $109.8 \mathrm{~mm}$ and was smaller than the result of a study in the waters of Kotabaru, which was 146.39 mm (RIMF, 2011). The difference of $L_{m}$ value in different waters is influenced by the availability of food and other environmental conditions, such as temperature and salinity. According to Udupa (1986), the $L_{m}$ value varies between species and within the same species. Further analysis revealed that the length at first capture $\left(L_{c}\right)$ of mud crabs in the waters of Kendari Bay was larger than the length at first maturity $\left(L_{m}\right)$. In the long term, this phenomenon would not disturb the sustainability of crab resources because it gives the mud crab broodstock an opportunity to spawn, ensuring repopulation. 
According to Sparre \& Venema (1999), the lower growth coefficient $(K)$ needed the longer time for the species to reach asymptotic length. On the other hand, the higher growth coefficient needed the shorter time by the species to approach the asymptotic length. The growth rate $(K)$ of mud crabs in the Kendari Bay waters was 1.01 per year and this showed that the growth rate was considered fast. This phenomenon differed from the results of other studies in various waters (Table 1).

Table 1. The growth rate $(K)$ and maximum carapace width $\left(L_{\infty}\right)$ of mud crabs $(S$. serrata) in some waters

\begin{tabular}{clcc}
\hline Waters & $\boldsymbol{K}$ (per tahun) & $\boldsymbol{L}_{\infty}(\mathbf{m m})$ & Sumber (Sources) \\
\hline Asahan & 1,38 & 200,1 & This research $(2016)$ \\
Kotabaru & 1,33 & 160,0 & RIMF $(2011)$ \\
Bone & 1,08 & 165,0 & RIMF $(2011)$ \\
Kutai Timur & $0,45-1,55$ & $147-155$ & Wijaya et al. $(2010)$ \\
Subang & 0,59 & 147,0 & Syam et al. $(2011)$ \\
Gorontalo & 0,39 & 188,49 & Monoarfa et al. $(2013)$ \\
Surabaya & 1,32 & 80,58 & Yusrudin $(2016)$ \\
\hline
\end{tabular}

The differences in growth parameter could be caused by the differences in maximum length of the samples collected and the differences in location of the waters (Widodo \& Suadi, 2006). Knaepkens et al. (2002) and Effendie (2002) stated that the differences in the values of $K$ and $L_{\infty}$ are caused by internal/intrinsic and external factors. The influential internal factors are genetics, parasite infestations, and diseases, while the external factors are temperature and availability of food.

The total mortality rate $(Z)$ is a combination of tnatural mortality rate $(M)$ and fishing mortality rate ( $F$ ) (Sparre \& Venema, 1999). The $M$ value of mud crabs in Kendari Bay waters appeared to be smaller than the $F$ value. This suggests that most of mud crabs in Kendari Bay waters died due to capture. Using the value of $F$, which describes the fishing pressure, and the value of $Z$, which reflects total mortality rate, the exploitation rate $(E)$ of mud crabs was 0.68 per year. If compared to the criteria set by Pauly et al. (1984), who stated that the optimum exploitation rate is 0.5 , the exploitation rate of mud crabs in the waters of Kendari Bay had exceeded the optimum exploitation rate. This demonstrates that the exploitation rate of mud crabs had reached $136 \%$, which is already in the overfishing category. Therefore,the mud crab resources in Kendari Bay waters should be preserved. Moreover, the fishing effort needs to be deducted of approximately $36 \%$ from the current effort.

\section{CONCLUSION AND SUGGESTIONS Conclusion}

The growth pattern of mud crabs in the waters of Kendari Bay and surrounding areas was negative allometric and this suggested that the body width growth was faster than the weight gain. The length at first captured $\left(L_{c}\right)$ was larger than the length at first maturity $\left(L_{m}\right)$ and in the long term would ensure the sustainability of the resource. The growth rate and the mortality rate of the mud crabs were categorized as high; therefore, extra care needs to be taken in selecting the management options. The exploitation rate of mud crab resources in Kendari Bay waters are already within the overfishing category and there needs to be a reduction in the effort.

\section{Suggestions}

In order to ensure the sustainability of mud crab resources in Kendari Bay waters and surrounding areas, there needs to be a reduction of approximately $36 \%$ of the current effort. In addition, there should be a study from socio-economic aspect so that the mud crab fishery status in Kendari Bay waters could be more accurately assessed.

\section{ACKNOWLEDGMENT}

This article is a part of Research of Fishery Biological Characteristics, Resource Habitats, and Fish Resource Production Potential in FMA 714 Banda Sea in 2016 that was supported by Research Institute for Marine Fisheries, Jakarta. The authors would like to thank Dr. Khairul Amri, M.Si as the Person in Charge of the Fisheries Management Area (FMA 714 the Year 2016) Research.

\section{REFERENCES}

Alamsyah, R., \& Megawati (2017). The relationship of carapace width and weight of mud crab in east coast of Sinjai. Proceeding of Crustacea Symposisum. MMAF-WWF-IPB.

Ball, D.V., \& Rao, K.V. (1984). "Marine fisheries" (p. 5-24). New Delhi/ : Tata Mc. Graw-Hill Publishing Company Limited. 
Central Bureau of Statistics/CBS. (2018). https:// www.bps.go.id/statictable/2014/09/08/1020/ ekspor-kepiting-dan-kerang-kerangan-menurutnegara-tujuan-utama-2002-2015.html. Accessed on February $27^{\text {th }}, 2018$ at 09.45.

Cholik, F. (1999). Review of mud crab culture research in Indonesia. Proceeding of Mud Crab Aquaculture and Biology. Australian Centre for International Agricultural Research, (ACIAR), Canberra, (78), 1420.

Cristensen, S. M., Macintosh, D., J \& Phuong, N. T. (2004). Pond production of the mud crabs Scylla paramamosain (Estampador) and $S$. olivacea (Herbst) in the Mekong Delta, Vietnam, using two different supplementary diets. Aqua. Res, 35, 1013-1024.

Directorate General of Capture Fisherie (DGCF). (2017). Fisheries statistic. Ministry of Marine Affair and Fisheries.

Edrus, I. N., \& Syam, A.R. (2004). Analysis of rakang and trap catch at crab fishing study in Mangrove waters, Maluku. J.Lit.Perik. Ind, 10 (4), 77 86.DOI: http://dx.doi.org/10.15578/ jppi.10.4.2004.77-86.

Effendie, M. I. (2002). Fishery biology (p. 136). Yayasan Pustaka Nusatama, Yogyakarta.

Fauzi, M., Prasetyo, A. P., Hargiyatno, T. I., Satria, F., \& Utama, A. A. (2013). The relationship and condition factor of spiny lobster (Panulirus penicillatus) in waters of Gunung Kidul and Pacitan. Bawal, 5(2), p. 97-102. DOI: http:// dx.doi.org/10.15578/bawal.5.2.2013.97-102.

Gayanilo, F. C. Jr, P. Sparre., \& D. Pauly (1993). The FISAT user's guide. FAO Computerized Information Series Fisheries. ICLARM - DIFMAR.

Gunarto., Daud R., \& Usman. (1999). Decrease trend of mud crab population in estuary waters of Cenranae river, South Sulawesi base of analysis of resources parameter. J.Lit.Perik. Ind, V (3), 30-37.

Kathirvel, M., Kulasekhar, S., \& Balasubramanium, C. P. (2004). Mud crab culture in India. Central Institute of Brackish water Aquaculture (ICAR), 17,60 .

Keenan, C.P., Davie, P.J.F. \& Mann, D.L. (1998). A revision of the genus Scylla De HAAN, 1983
(Crustacea: Decapoda: Brachyura: Portunidae). The Raffles Bulletin of Zoology, 46 (1), 217-245.

Kembaren, D., Ernawati, T., Rijal, M., Pane. A.R., Setiawan, R., \& Yusuf, H.N, (2015). The study of stock, exploitation level and fishing capacity of shrimp and others crustacean resources in Fishing Management Area 714- Tolo Bay and Banda Sea. Final Report, Research Institute for Marine Fisheries Jakarta.

Knaepkens, G., Knapen, D, Bervoets, L., Hanfling, B., Verheyen, E., \& Eens, M. (2002). Genetic diversity and condition factor: a significant relationship in Flemish but not in German populations of the the European bullhead (Cottus gobio L.). Heredity, 89, 280-287.

Le Vay, L. (1998). Ecology and stock assessment of Scylla spp. In: Proceedings of the International Forum on the Culture of Portunid Crabs, Boracay, Philippines, December, 1-4.

Marichamy, R., \& Rajapackian, S. (2001). The aquaculture of Scylla species in India. Asian Fish. Sci, 14, 231-238.

Mohanty, S. K., Mohapatra, A., Mohanty, R. K., Bhatta, R. K., \& Pattnaik, A. K. (2006). Occurrence and biological outlines of two species of Scylla (De Haan) in Chilika lagoon, India. Ind. J. Fish, 53, 191-202.

Monoarfa, S., Syamsuddin., \& Hamzah, S.N. (2013). Analysis of population dynamic parameters of mud crab (Scylla serrata) in Kwandang waters, North Gorontalo District. Jurnal IImiah Perikanan dan Kelautan. 1(1), 31-36.

Pauly, D. (1980). A Selection of a simple methods for the assessment of the tropical fish stock. FAO Fish. Circ. FIRM/ C 729. Roma. p. 54.

Pauly, D., Ingles, J., \& Neal, R. (1984). Application to shrimp stocks of objective methods for the estimation of growth, mortality and recruitment related parameters from length frequency data (ELEFAN I and II) (p. 220-234). In : Penaeid shrimptheir biology and management: Fishing News Book Limited. Farnham-Surrey-England.

RIMF (2011). The research and exploitation of penaeid shrimp and others crustacean resources in Fishing Management Area of Makassar Strait, Flores Sea and Bone Bay. Final Report. Research Institute for Marine Fisheries (RIMF), Jakarta. 
Ruscoe, I. M., Shelley, C. C., \& Williams, G. R. (2004). The combined effects of temperature and salinity on growth and survival of juvenile mud crabs (Scylla serrata Forskal). Aquaculture, 238, 239247.

Sparre, P., \& Venema, S. (1999). Introduction to Tropical Fish Stock Assessment. (Introduksi Pengkajian Stok Ikan Tropis (p. 438), alih bahasa -: Pusat Penelitian dan Pengembangan Perikanan). Buku 1: Manual. Badan Penelitian dan Pengembangan Perikanan. Jakarta.

Sudjastani, T. (1974). Dinamika populasi ikan kembung di laut Jawa. Laporan Penelitian Perikanan Laut, (1), 30-64.

Suman, A. (2004). Exploitation pattern of endeavour shrimp resourcesl (Metapenaeus ensis de Haan) in Cilacap and its adjacent waters. Dissertation in IPB, Bogor.

Syam, A. R., Suwarso., \& Purnamaningtyas, S.E. (2011). Exploitation rate of mud crab (Scylla serrata) in Mayangan mangrove waters, Subang West Java. J.Lit.Perik.Ind, 17 (3), 201 - 207. DOI: http://dx.doi.org/10.15578/jppi.17.3.2011.201-207.

Widodo, J., \& Suadi. (2006). Management of marine fisheries resources. Universitas Gadjah Mada (ID) Press., Yogyakarta.

Wijaya N.I., Yulianda F., Boer M., \& Juwana S. (2010). Population biology of mud crab (Scylla serrata F.) in Kutai Mangrove Habitat, East Kutai District. Jurnal Oseanografi dan Limnologi di Indonesia, (3), 443-461.

Udupa, K. S. (1986). Statistical method of estimating the size at first maturity of fishes. Fishbyte, 4(2), 8-10.

Yusrudin (2016). Analysis of some biological aspect of mud crab (Scylla serrata) in Sukolilo waters, Surabaya east coast. Proceeding of Marine National Seminar. Trunojoyo University, Madura. 